\title{
EDITORIAL
}

\section{Introducing the First European Symposium on the Evolution of Crocodylomorpha}

\author{
EDUARDO PUÉRTOLAS-PASCUAL ${ }^{1,2,3, *, \oplus,}$ MARK T. YOUNG ${ }^{4}$ and \\ CHRISTOPHER A. BROCHU ${ }^{5}$
}

\author{
${ }^{1}$ Faculdade de Ciências e Tecnologia-GeoBioTec, NOVA University of Lisbon, Monte de Caparica, \\ Caparica 2829-516, Portugal \\ ${ }^{2}$ Museu da Lourinhã, Lourinhã 2530-158, Portugal \\ ${ }^{3}$ Aragosaurus-IUCA Research Group, Universidad de Zaragoza, Zaragoza 50009, Spain \\ ${ }^{4}$ School of GeoSciences, Grant Institute, The King's Buildings, University of Edinburgh, James Hutton \\ Road, Edinburgh EH9 3FE, UK \\ ${ }^{5}$ Department of Earth and Environmental Sciences, University of Iowa, Iowa City 52242, IA, USA
}

Received 27 January 2020; accepted for publication 31 January 2020

\begin{abstract}
The First European Symposium on the Evolution of Crocodylomorpha took place during the XVI Annual Meeting of the European Association of Vertebrate Palaeontologists (EAVP) organized by NOVA University of Lisbon (UNL) in Caparica, Portugal. Fourteen lectures and five posters were presented at the symposium in June 26th-July 1 st, 2018. This special issue showcases twelve papers based on symposium contributions.
\end{abstract}

ADDITIONAL KEYWORDS: Crocodylomorpha - Crocodyliformes - Crocodylia - evolution.

More than a decade has passed since the First Symposium on the Evolution of Crocodyliformes. Taking place in Neuquén, Argentina, during 2009, the results of that symposium were published as a special volume in this journal in 2011 (Pol \& Larsson, 2011, and articles therein). Since then, the second symposium was held in 2011 in San Juan, Argentina, and a third was held in October 2019 in Uberlândia, Brazil. Following in the footsteps of these symposia, the First European Symposium on the Evolution of Crocodylomorpha took place during the XVI Annual Meeting of the European Association of Vertebrate Palaeontologists (EAVP) organized by NOVA University of Lisbon (UNL) in Caparica, Portugal (Fig. 1).

The symposium was a success, featuring a fascinating keynote presentation by Dr Christopher Brochu, along with 13 oral presentations and five posters. This special volume was commissioned from these presentations, yielding twelve published

*Corresponding author. E-mail: eduardo.puertolas@gmail.com articles. It covers an array of crocodylomorph taxa ranging from the Jurassic to the present, including thalattosuchians, advanced neosuchians, basal eusuchians and crocodylians. Moreover, the included studies cover an array of topics (cladistics, systematics, functional anatomy and biodiversity) largely focused on European material, although global studies and those from other continents (such as South America) have also been included.

The First European Symposium on the Evolution of Crocodylomorpha, and this special issue of the Zoological Journal of the Linnean Society, reflects the advances and new crocodylomorph discoveries made in Europe during the past decade. These ten years have seen a renaissance of study into crocodylomorph evolution (Fig. 2) in Europe, spanning the discovery of new specimens, re-descriptions of historical specimens and advances in model-based macroevolutionary analyses.

One of the neosuchian clades reviewed over the last decade in Europe is the Goniopholididae. This 


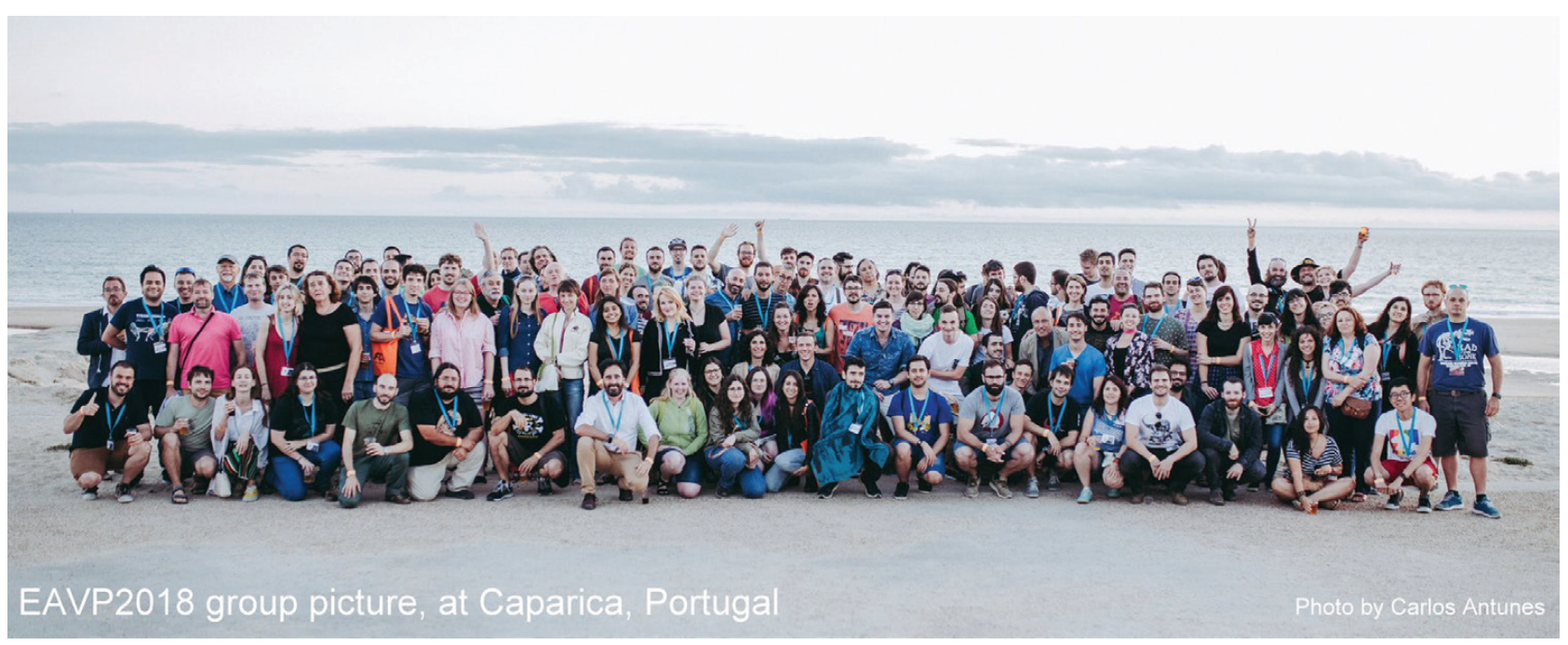

Figure 1. Group photograph of the participants in the XVI Annual Meeting of the European Association of Vertebrate Palaeontologists (EAVP).

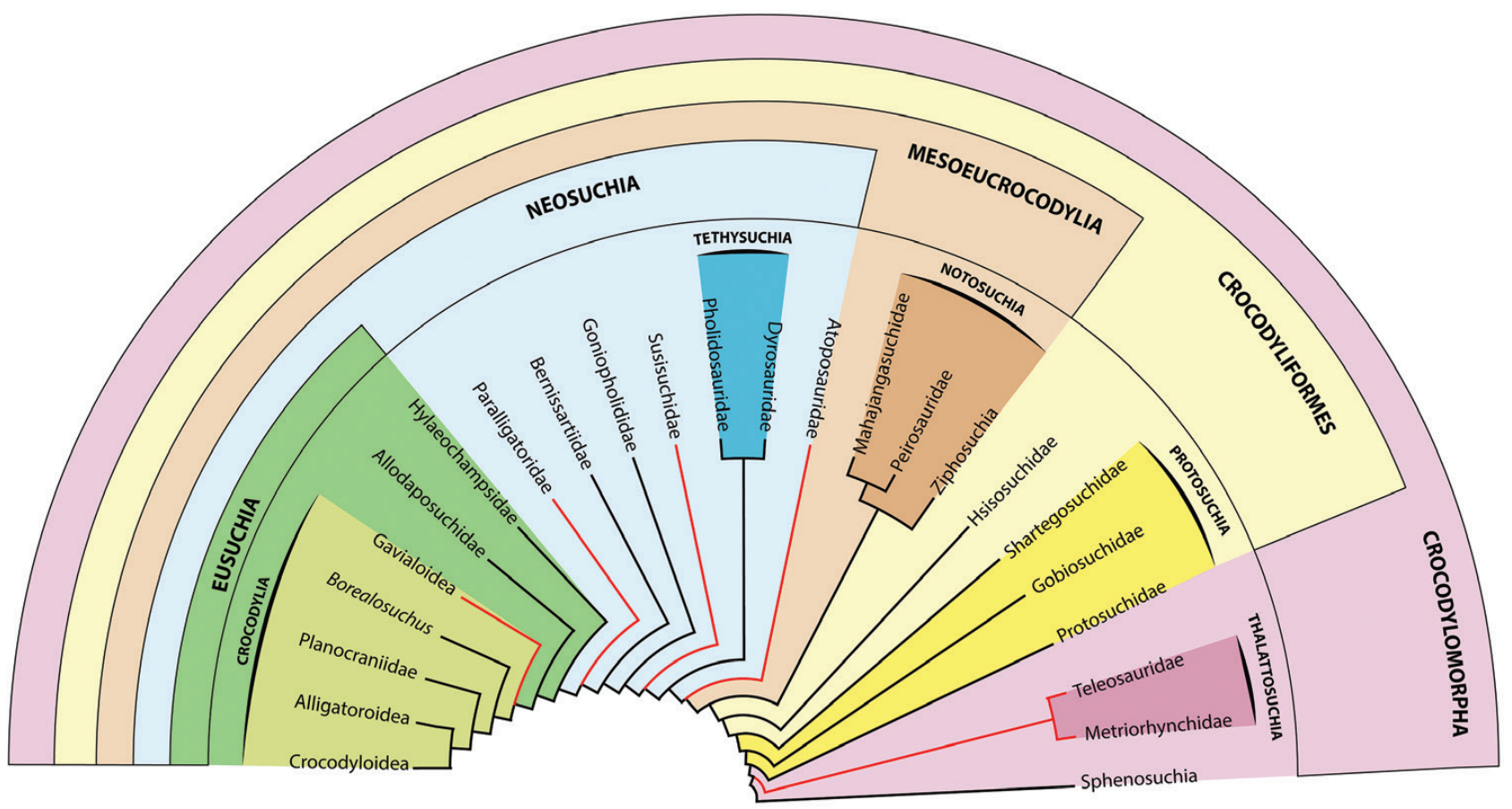

Figure 2. Morphology phylogeny of the main lineages within the Crocodylomorpha based on recent studies such as Pol \& Leardi (2015), Wilberg (2015), Buscalioni (2017), Dal Sasso et al. (2017), Barrios et al. (2018), Mateus et al. (2019), Wilberg et al. (2019). Clades with red lines indicate taxa whose phylogenetic position is still under strong debate.

clade includes Jurassic/Cretaceous forms with a semi-aquatic lifestyle, a Laurasian distribution and a general gestalt reminiscent of extant crocodylians. One of the most common taxa in the fossil record of the Late Jurassic and Early Cretaceous of Europe is Goniopholis. Since the first Goniopholis was discovered and described, this genus has been used as a "wastebasket" taxon for a variety of fragmentary goniopholidids (Andrade et al., 2011), with as many as 19 species included within the genus (Salisbury $\&$ Naish, 2011). However, in the last few years, and thanks to new discoveries of several specimens, an 
exhaustive review of Eurasian goniopholidids has been undertaken (Andrade \& Hornung, 2011; Andrade et al., 2011; Salisbury \& Naish, 2011; Buscalioni et al., 2013; Puértolas-Pascual et al., 2015a; Martin et al., 2016b; Ristevski et al., 2018; Puértolas-Pascual \& Mateus, 2020). As a consequence of these works, the genus Goniopholis is now restricted to three species and the remaining European species have been considered nomina dubia, junior synonyms or have been reassigned to the new genera Hulkepholis (Salisbury \& Naish, 2011; Buscalioni et al., 2013; Arribas et al., 2019) and Anteophthalmosuchus (Salisbury \& Naish, 2011; Buscalioni et al., 2013; Puértolas-Pascual et al., 2015a; Martin et al., 2016b; Ristevski et al., 2018).

There has been a revolution in our understanding of the small-bodied taxa spanning the transition from "advanced" neosuchians to basal eusuchians over the past decade. Indeed, the number of such forms has exploded since the turn of the millennium. But some of these forms are phylogenetically problematic. This is especially true of atoposaurids. These were diminutive crocodyliforms that were important components of Laurasian semi-aquatic and terrestrial ecosystems during the Jurassic and Cretaceous. Our sample of such forms has expanded greatly in the past decade (e.g. Martin et al., 2010, 2014a; Tennant \& Mannion, 2014; Puértolas-Pascual et al., 2015b, 2016; Tennant et al., 2016; Young et al., 2016; Venczel \& Codrea, 2019), but whether "Atoposauridae" as classically understood represents a clade is unclear, nor is it clear how many taxa these fossils represent. A recent review by Tennant et al. (2016) concluded that only three Late Jurassic genera from western Europe (Alligatorellus, Alligatorium, Atoposaurus) should be included in Atoposauridae, and that the putative atoposaurid genus Theriosuchus was polyphyletic, with none of its component species referable to the Atoposauridae. Subsequent studies have reinforced the non-monophyly of Theriosuchus, but argued for an atoposaurid affinity for all such forms, with atoposaurids closely related to the Paralligatoridae within the Eusuchia (e.g. Schwarz et al. (2017)). Further review of historical material is needed in parallel with the description of new taxa.

An endemic European clade important for our understanding of eusuchian origins is Bernissartiidae. This small-bodied clade is unique in having dentition adapted to a durophagous diet. Originally known only from Bernissartia fagesii Dollo, 1883 from the Early Cretaceous of Belgium, new material has been discovered and described from Spain (PuértolasPascual et al. (2015b) and references therein). Recently, a new bernissartiid species based on a complete skull from the Early Cretaceous of England was named Koumpiodontosuchus aprosdokiti Sweetman, Pedreira-Segade \& Vidovic, 2015.
Perhaps nothing has done more to advance our understanding of eusuchian and crocodylian origins than a series of studies exploring the systematics, phylogeny and palaeobiogeography of two endemic European radiations, the Hylaeochampsidae (Martin, 2007; Delfino et al., 2008b; Buscalioni et al., 2011) and Allodaposuchidae (Delfino et al., 2008a; Martin \& Buffetaut, 2008; Puértolas et al., 2011; Blanco et al., 2014; Puértolas-Pascual et al., 2014; Blanco et al., 2015; Narváez et al., 2015; Martin et al., 2016a; Narváez et al., 2016; Blanco \& Brochu, 2017; Narváez et al., 2017) (Table 1). There has also been the discovery of a putative Middle Jurassic hylaeochampsid from the Isle of Skye, Scotland (Yi et al., 2017).

The European fossil record of crown-group Crocodylia has been elucidated. These studies have ranged from the discovery of new taxa to reassessments of the morphology, phylogeny, taxonomy and palaeobiogeography of typical European taxa, such as the Palaeocene/Eocene crocodyloid Asiatosuchus (Delfino \& Smith, 2009; Delfino et al., 2017), the Eocene/Miocene alligatoroid Diplocynodon (Martin, 2010; Delfino \& Smith, 2012; Martin et al., 2014b; Díaz Aráez et al., 2017; Rio et al., 2020) and the Eocene tomistomine Kentisuchus (Jouve, 2016). In addition, the palaeobiodiversity (Mannion et al., 2015; Puértolas-Pascual et al., 2016; Wilberg, 2017) and phylogenetic relationships (Groh et al., 2020) of the Crocodylia through the Mesozoic and Cenozoic have been explored. Recently, the description of Portugalosuchus from the Late Cretaceous of Portugal hints that this new eusuchian could be the oldest known member of the crowngroup, pushing back the origins of the Crocodylia by 20 million years, and suggests that the European archipelago of the 'mid' Cretaceous could be the origin of this clade (Mateus et al., 2019).

Finally, there has been a renaissance in the study of European non-neosuchian crocodylomorphs, particularly for the Thalattosuchia. These include the re-study of historical specimens (e.g. Jouve, 2009; Young \& Andrade, 2009; Johnson et al., 2015, 2018; Sachs et al., 2019a; Cau, 2019; Rio et al., 2020), naming of new genera and/or species (e.g. Young et al., 2010, 2013; Cau \& Fanti, 2011; Parrilla-Bel et al., 2013; Foffa et al., 2018a; Sachs et al., 2019b, Aiglstorfer et al., 2020), descriptions of isolated elements (Chiarenza et al., 2015; Parrilla-Bel \& Canudo, 2015), and how thalattosuchians ecologically interacted with other marine reptile groups (Foffa et al., 2018b). There has also been renewed interest in the European notosuchians (e.g. Rabi \& Sebok, 2015; Martin, 2016; Cubo et al., 2017), and in the non-mesoeucrocodylian crocodylomorphs related to the Gobiosuchidae (Schwarz \& Fechner, 2008; Buscalioni, 2017). 


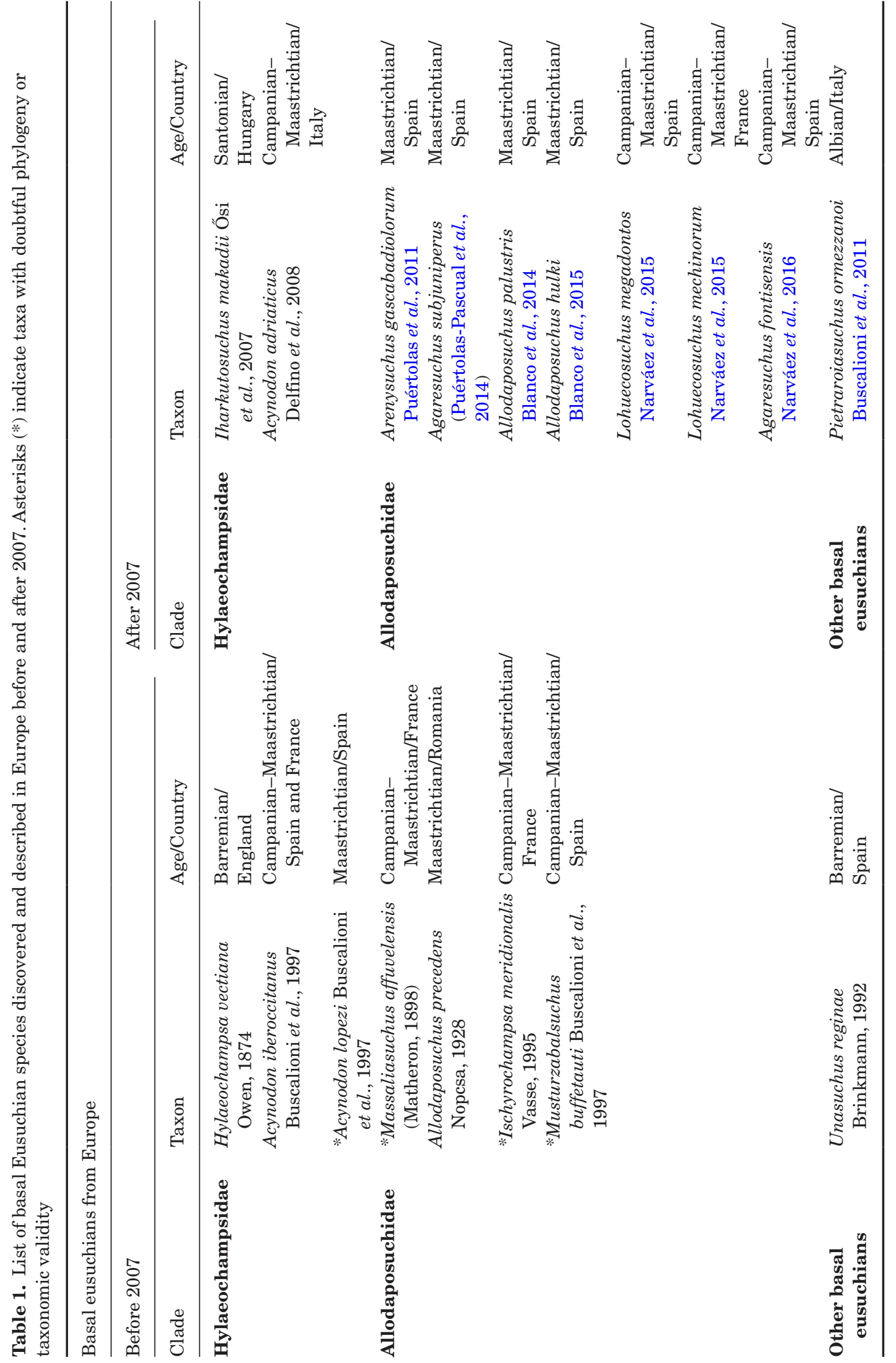


Following the call of the First European Symposium on the Evolution of Crocodylomorpha and this special volume, twelve new articles have been here included:

From the Jurassic-Early Cretaceous, there are four articles on the marine crocodylomorph clade Thalattosuchia. The first article makes a review of the teleosauroid genus Steneosaurus. This genus has been used as a wastebasket taxon since the 19th century, consequently, the authors consider it an undiagnostic and invalid genus and, therefore, new genera should be erected (Johnson et al., 2020a). Following these steps, the second study re-describes two historical species of teleosauroids, Steneosaurus larteti EudesDeslongchamps, 1869 and S. boutilieri Bronzati et al., 2012, from the Bathonian (Middle Jurassic) of England (Johnson et al., 2020b). This study confirmed the validity of these two species, but reassigned them to the new genera Deslongchampsina and Yvridiosuchus, respectively. Moreover, the re-description of these taxa hints that macrophagous/durophagous teleosauroids evolved prior to the Bathonian, and further elucidates the early evolution of the subclade Machimosaurini. The third article is about the other great clade within the Thalattosuchia: the Metriorhynchoidea. Here, Young et al. (2020a) described isolated tooth crowns, and the occipital region of a large Torvoneustes specimen from the Late Jurassic of England. They showed that at least some species of Torvoneustes could rival the giant metriorhynchid, Plesiosuchus, in body size. The fourth article related to the Thalattosuchia investigates posterodorsal retraction of the external nares in metriorhynchids. They found that this adaptation to a sustained swimming ecology evolved independently several times; however, curiously, unlike in other groups of Mesozoic marine reptiles, metriorhynchids evolved from taxa with a single naris at the tip of the snout (Young et al., 2020b).

Two articles on continental crocodylomorphs from the Jurassic of Portugal are also included. The first, focusing on the Late Jurassic of the Lourinhã Formation (Portugal), describes a three-dimensionally preserved articulated partial skeleton of a small goniopholidid. Comparative microCT datasets, comprising this specimen and other neosuchians yielded new inferences about the evolution and functionality of the dermal armour in goniopholidids (Puértolas-Pascual \& Mateus, 2020). The second article focuses on crocodylomorph teeth from the same Formation. Over 120 teeth were studied and assigned to ten different morphotypes, which were then attributed to five different clades: the Atoposauridae, Goniopholididae, Bernissartiidae, Lusitanisuchus and an undetermined crocodylomorph. This study not only addresses the palaeobiodiversity of the Lourinhã crocodylomorph fauna, but also explores their ecological relationships. Based on the different dental morphologies, four distinct feeding behaviours (durophagous, "insectivorous", hypercarnivorous and generalist) are hypothesized (Guillaume et al., 2020).

We include another tooth-based study, this time based on material from the Maastrichtian of Spain. In this study, several isolated tooth crowns, and maxillary and mandibular remains recovered in the Tremp Formation (southern Pyrenees) are described and analysed. Based on the tooth morphological variation and taphonomy of each site, the crocodylomorph assemblage is found to be highly diverse, in terms of species richness, inferred feeding habits and environmental preferences (Blanco et al., 2020).

This volume also includes a paper on the systematics and phylogeny of the Allodaposuchidae. The study provides a detailed review of the historic material from the Maastrichtian of Romania assigned to Allodaposuchus precedens Nopcsa, 1928. From this, a new diagnosis for this taxon and comparisons with other allodaposuchids are presented and discussed (Narváez et al., 2020).

Two papers focus on eusuchian evolution. The first is an analysis of the spatiotemporal distribution of Eusuchia (De Celis et al., 2020). This paper finds several peaks in eusuchian palaeodiversity, with the largest in the Palaeocene and the middle-late Miocene. The study also suggests that eusuchian palaeodiversity could be linked to the palaeotemperature (among other abiotic and/or biotic factors). The second study (Cidade et al., 2020) looks into the taxonomy and phylogeny of the alligatoroid Necrosuchus ionensis Simpson, 1937. This study recovers Necrosuchus as a derived caimanine, as it lived during the Palaeocene eusuchian palaeodiversity maximum in South America, suggesting new perspectives on the early evolution and radiation of caimanines.

Another in this special issue investigates the robustness and homoplasy of morphological characters used in crown crocodylian phylogenies (Sookias, 2020). The impetus for this study is the discordance between morphological and DNA-based phylogenies of extant crocodylians, primarily in the position of the Indian gharial. This study provides some indications as to how morphology may be able to be used in a more effective way for crocodylians, but also for other crocodylomorphs. The final work, on which the main keynote of the symposium was based, deals with the problem of cryptic species in Crocodylia (Brochu \& Sumrall, 2020). In recent years, a multitude of cryptic species are being discovered within the extant crocodylians. These work raises both a dilemma (how to recognize cryptic species with minimal morphological variations in the fossil record) and an opportunity, since the number of fossil species that currently exist could increase.

Ten major crocodylomorph clades - the Metriorhynchidae, Teleosauroidea, Ziphosuchia, Goniopholididae, Atoposauridae, Bernissartiidae, 
Hylaeochampsidae, Allodaposuchidae, Eusuchia and Crocodylia - are approached in this volume from systematic, phylogenetic, palaeobiodiversity, palaeobiogeographical and palaeoecological points of view. All these contributions will impact crocodyliform research and shall serve to expand the knowledge of all these clades in particular, and Crocodylomorpha in general.

\section{REFERENCES}

Aiglstorfer M, Havlik P, Herrera Y. 2020. The first metriorhynchoid crocodyliform from the Aalenian (Middle Jurassic) of Germany, with implications for the evolution of Metriorhynchoidea. Zoological Journal of the Linnean Society 188: 522-551.

Andrade MB, Edmonds R, Benton MJ, Schouten R. 2011. A new Berriasian species of Goniopholis (Mesoeucrocodylia, Neosuchia) from England, and a review of the genus. Zoological Journal of the Linnean Society 163: S66-S108.

Andrade MB, Hornung JJ. 2011. A new look into the periorbital morphology of Goniopholis (Mesoeucrocodylia: Neosuchia) and related forms. Journal of Vertebrate Paleontology 31: 352-368.

Arribas I, Buscalioni AD, Torres RR, Espílez E, Mampel L, Alcalá L. 2019. A new goniopholidid crocodyliform, Hulkepholis rori sp. nov. from the Camarillas Formation (early Barremian) in Galve, Spain). PeerJ 7: e7911.

Barrios F, Bona P, Paulina-Carabajal A, Gasparini Z. 2018. Re-description of the cranio-mandibular anatomy of Notosuchus terrestris (Crocodyliformes, Mesoeucrocodylia) from the Upper Cretaceous of Patagonia. Cretaceous Research 83: 3-39.

Blanco A, Brochu CA. 2017. Intra- and interspecific variability in allodaposuchid crocodylomorphs and the status of western European taxa. Historical Biology 29: 495-508.

Blanco A, Fortuny J, Vicente A, Luján ÀH, GarcíaMarçà JA, Sellés AG. 2015. A new species of Allodaposuchus (Eusuchia, Crocodylia) from the Maastrichtian (Late Cretaceous) of Spain: phylogenetic and paleobiological implications. PeerJ 3: e1171.

Blanco A, Puértolas-Pascual E, Marmi J, MoncunillSolé B, Llácer S, Rössner GE. 2020. Late Cretaceous (Maastrichtian) crocodyliforms from north-eastern Iberia: a first attempt to explain the crocodyliform diversity based on tooth qualitative traits. Zoological Journal of the Linnean Society 189: 584-617.

Blanco A, Puértolas-Pascual E, Marmi J, Vila B, Sellés AG. 2014. Allodaposuchus palustris sp. nov. from the Upper Cretaceous of Fumanya (South-Eastern Pyrenees, Iberian Peninsula): Systematics, palaeoecology and palaeobiogeography of the enigmatic Allodaposuchian Crocodylians. PLoS One 9: 1-34.

Brochu CA, Sumrall CD. 2020. Modern cryptic species and crocodylian diversity in the fossil record. Zoological Journal of the Linnean Society 189: 700-711.
Buscalioni ÁD. 2017. The Gobiosuchidae in the early evolution of Crocodyliformes. Journal of Vertebrate Paleontology 37: e1324459.

Buscalioni AD, Alcala L, Espilez E, Mampel L. 2013. European Goniopholididae from the Early Albian Escucha Formation in Arino (Tereuel, Aragon, Spain). Spanish Journal of Paleontology 28: 103-121.

Buscalioni AD, Piras P, Vullo R, Signore M, Barbera C. 2011. Early Eusuchia Crocodylomorpha from the vertebraterich Plattenkalk of Pietraroia (Lower Albian, southern Apennines, Italy). Zoological Journal of the Linnean Society 163: S199-S227.

Cau A. 2019. A revision of the diagnosis and affinities of the metriorhynchoids (Crocodylomorpha, Thalattosuchia) from the Rosso Ammonitico Veronese Formation (Jurassic of Italy) using specimen-level analyses. PeerJ 7: e7364.

Cau A, Fanti F. 2011. The oldest known metriorhynchid crocodylian from the Middle Jurassic of north-eastern Italy: Neptunidraco ammoniticus gen. et sp. nov. Gondwana Research 19: 550-565.

Chiarenza AA, Foffa D, Young MT, Insacco G, Cau A, Carnevale G, Catanzariti R. 2015. The youngest record of metriorhynchid crocodylomorphs, with implications for the extinction of Thalattosuchia. Cretaceous Research 56: 608-616.

Cidade GM, Fortier D, Hsiou AS. 2020. Taxonomic and phylogenetic review of Necrosuchus ionensis (Alligatoroidea: Caimaninae) and the early evolution and radiation of caimanines. Zoological Journal of the Linnean Society 189: 657-669.

Cubo J, Köhler M, de Buffrénil V. 2017. Bone histology of Iberosuchus macrodon (Sebecosuchia, Crocodylomorpha). Lethaia 50: 495-503.

De Celis A, Narváez I, Ortega F. 2020. Spatiotemporal palaeodiversity patterns of modern crocodiles (Crocodyliformes: Eusuchia). Zoological Journal of the Linnean Society 189: 635-656.

Delfino M, Codrea V, Folie A, Dica P, Godefroit P, Smith T. 2008a. A complete skull of Allodaposuchus precedens Nopcsa, 1928 (Eusuchia) and a reassessment of the morphology of the taxon based on the Romanian remains. Journal of Vertebrate Paleontology 28: 111-122.

Delfino M, Martin JE, Buffetaut E. 2008b. A new species of Acynodon (Crocodylia) from the Upper Cretaceous (Santonian-Campanian) of Villaggio del Pescatore, Italy. Palaeontology 51: 1091-1106.

Delfino M, Martin JE, de Lapparent de Broin F, Smith T. 2017. Evidence for a pre-PETM dispersal of the earliest European crocodyloids. Historical Biology 2963: 1-8.

Delfino M, Smith T. 2009. A reassessment of the morphology and taxonomic status of 'Crocodylus' depressifrons Blainville, 1855 (Crocodylia, Crocodyloidea) based on the Early Eocene remains from Belgium. Zoological Journal of the Linnean Society 156: $140-167$.

Delfino M, Smith T. 2012. Reappraisal of the morphology and phylogenetic relationships of the middle Eocene alligatoroid Diplocynodon deponiae (Frey, Laemmert, and Riess, 
1987) based on a three-dimensional specimen. Journal of Vertebrate Paleontology 32: 1358-1369.

Díaz Aráez JL, Delfino M, Luján ÀH, Fortuny J, Bernardini F, Alba DM. 2017. New remains of Diplocynodon (Crocodylia: Diplocynodontidae) from the Early Miocene of the Iberian Peninsula. Comptes Rendus Palevol 16: 12-26.

Foffa D, Young MT, Brusatte SL, Graham MR, Steel L. 2018a. A new metriorhynchid crocodylomorph from the Oxford Clay Formation (Middle Jurassic) of England, with implications for the origin and diversification of Geosaurini. Journal of Systematic Palaeontology 16: 1123-1143.

Foffa D, Young MT, Stubbs TL, Dexter KG, Brusatte SL. 2018b. The long-term ecology and evolution of marine reptiles in a Jurassic seaway. Nature Ecology \& Evolution 2: 1548-1555.

Groh SS, Upchurch P, Barrett PM, Day JJ. 2020. The phylogenetic relationships of neosuchian crocodiles and their implications for the convergent evolution of the longirostrine condition. Zoological Journal of the Linnean Society 188: 473-506.

Guillaume ARD, Moreno-Azanza M, Puértolas-Pascual E, Mateus O. 2020. Palaeobiodiversity of crocodylomorph from the Lourinhã Formation based on the tooth record: insights into the palaeoecology of the Late Jurassic of Portugal. Zoological Journal of the Linnean Society 189: 549-583.

Johnson MM, Young MT, Brusatte SL. 2020a. Emptying the wastebasket: a historical and taxonomic revision of the Jurassic crocodylomorph Steneosaurus. Zoological Journal of the Linnean Society 189: 449-482.

Johnson MM, Young MT, Brusatte SL. 2020b. Re-description of two contemporaneous mesorostrine teleosauroids (Crocodylomorpha: Thalattosuchia) from the Bathonian of England and insights into the early evolution of Machimosaurini. Zoological Journal of the Linnean Society 189: 428-448.

Johnson MM, Young MT, Brusatte SL, Thuy B, Weis R. 2018. A catalogue of teleosauroids (Crocodylomorpha: Thalattosuchia) from the Toarcian and Bajocian (Jurassic) of southern Luxembourg. Historical Biology 2963: 1-16.

Johnson MM, Young MT, Steel L, Lepage Y. 2015. Steneosaurus edwardsi (Thalattosuchia: Teleosauridae), the largest known crocodylomorph of the Middle Jurassic. Biological Journal of the Linnean Society 115: 911-918.

Jouve S. 2009. The skull of Teleosaurus cadomensis (Crocodylomorpha; Thalattosuchia), and phylogenetic analysis of Thalattosuchia. Journal of Vertebrate Paleontology 29: $88-102$.

Jouve S. 2016. A new basal tomistomine (Crocodylia, Crocodyloidea) from Issel (Middle Eocene; France): Palaeobiogeography of basal tomistomines and palaeogeographic consequences. Zoological Journal of the Linnean Society 177: 165-182.

Mannion PD, Benson RBJ, Carrano MT, Tennant JP, Judd J, Butler RJ. 2015. Climate constrains the evolutionary history and biodiversity of crocodylians. Nature Communications 6: 1-9.

Martin JE. 2007. New material of the Late Cretaceous Globidontan Acynodon iberoccitanus (Crocodylia) from southern France. Journal of Vertebrate Paleontology 27: 362-372.

Martin JE. 2010. A new species of Diplocynodon (Crocodylia, Alligatoroidea) from the Late Eocene of the Massif Central, France, and the evolution of the genus in the climatic context of the Late Palaeogene. Geological Magazine 147: 596-610.

Martin JE. 2016. Nouveau matériel du crocodylomorphe ziphodonte Iberosuchus de l'Éocène du Languedoc, sud de la France. Annales de Paleontologie 102: 135-144.

Martin JE, Buffetaut E. 2008. Crocodilus affuvelensis Matheron, 1869 from the Late Cretaceous of southern France: a reassessment. Zoological Journal of the Linnean Society 152: 567-580.

Martin JE, Delfino M, Garcia G, Godefroit P, Berton S, Valentin X. 2016a. New specimens of Allodaposuchus precedens from France: intraspecific variability and the diversity of European Late Cretaceous eusuchians. Zoological Journal of the Linnean Society 176: 607-631.

Martin JE, Delfino M, Smith T. 2016b. Osteology and affinities of Dollo's goniopholidid (Mesoeucrocodylia) from the Early Cretaceous of Bernissart, Belgium. Journal of Vertebrate Paleontology 36: e1222534.

Martin JE, Rabi M, Csiki Z. 2010. Survival of Theriosuchus (Mesoeucrocodylia: Atoposauridae) in a Late Cretaceous archipelago: a new species from the Maastrichtian of Romania. Die Naturwissenschaften 97: 845-854.

Martin JE, Rabi M, Csiki-Sava Z, Vasile Ş. 2014a. Cranial morphology of Theriosuchus sympiestodon (Mesoeucrocodylia, Atoposauridae) and the widespread occurrence of Theriosuchus in the Late Cretaceous of Europe. Journal of Paleontology 88: 444-456.

Martin JE, Smith T, de Lapparent de Broin F, Escuillié F, Delfino M. 2014b. Late Palaeocene eusuchian remains from Mont de Berru, France, and the origin of the alligatoroid Diplocynodon. Zoological Journal of the Linnean Society 172: 867-891.

Mateus O, Puértolas-Pascual E, Callapez PM. 2019. A new eusuchian crocodylomorph from the Cenomanian (Late Cretaceous) of Portugal reveals novel implications on the origin of Crocodylia. Zoological Journal of the Linnean Society 186: 501-528.

Narváez I, Brochu CA, De Celis A, Codrea V, Escaso F, Pérez-García A, Ortega F. 2020. New diagnosis for Allodaposuchus precedens, the type species of the European Upper Cretaceous clade Allodaposuchidae. Zoological Journal of the Linnean Society 189: 618-634.

Narváez I, Brochu CA, Escaso F, Pérez-Garcéa A, Ortega F. 2015. New crocodyliforms from southwestern Europe and definition of a diverse clade of European late cretaceous basal eusuchians. PLoS One 10: 1-34.

Narváez I, Brochu CA, Escaso F, Pérez-García A, Ortega F. 2016. New Spanish Late Cretaceous eusuchian reveals the synchronic and sympatric presence of two allodaposuchids. Cretaceous Research 65: 112-125.

Narváez I, Brochu CA, Escaso F, Pérez-García A, Ortega F. 2017. Analysis and phylogenetic status of the eusuchian fragmentary material from Western Europe 
assigned to Allodaposuchus precedens. Journal of Iberian Geology 43: 345-361.

Parrilla-Bel J, Canudo JI. 2015. Postcranial elements of 'Maledictosuchus riclaensis' (Thalattosuchia) from the Middle Jurassic of Spain. Journal of Iberian Geology 41: 31-40.

Parrilla-Bel J, Young MT, Moreno-Azanza M, et al. 2013. The first metriorhynchid crocodylomorph from the Middle Jurassic of Spain, with implications for evolution of the subclade Rhacheosaurini. PLoS One 8: e54275.

Pol D, Larsson HCE. 2011. 1st symposium on the evolution of crocodyliforms. Zoological Journal of the Linnean Society 163: S1-S6.

Pol D, Leardi JM. 2015. Diversity patterns of Notosuchia (Crocodyliformes, Mesoeucrocodylia) during the Cretaceous of Gondwana. Publicación Electrónica de la Asociación Paleontológica Argentina 15: 172-186.

Puértolas E, Canudo JI, Cruzado-Caballero P. 2011. A new crocodylian from the late Maastrichtian of Spain: implications for the initial radiation of crocodyloids. PLoS One 6: e20011.

Puértolas-Pascual E, Blanco A, Brochu CA, Canudo JI. 2016. Review of the Late Cretaceous-early Paleogene crocodylomorphs of Europe: extinction patterns across the K-PG boundary. Cretaceous Research 57: 565-590.

Puértolas-Pascual E, Canudo JI, Moreno-Azanza M. 2014. The eusuchian crocodylomorph Allodaposuchus subjuniperus sp. nov., a new species from the latest Cretaceous (upper Maastrichtian) of Spain. Historical Biology 26: 91-109.

Puértolas-Pascual E, Canudo JI, Sender LM. 2015a. New material from a huge specimen of Anteophthalmosuchus cf. escuchae (Goniopholididae) from the Albian of Andorra (Teruel, Spain): phylogenetic implications. Journal of Iberian Geology 41: 41-56.

Puértolas-Pascual E, Mateus O. 2020. A three-dimensional skeleton of Goniopholididae from the Late Jurassic of Portugal: implications for the Crocodylomorpha bracing system. Zoological Journal of the Linnean Society 189: 521-548.

Puértolas-Pascual E, Rabal-Garcés R, Ignacio Canudo J, Puértolas-Pascual Grupo E. 2015b. Exceptional crocodylomorph biodiversity of 'La Cantalera' site (lower Barremian; Lower Cretaceous) in Teruel, Spain. Palaeontologia Electronica 18: 1-16.

Rabi M, Sebok N. 2015. A revised Eurogondwana model: Late Cretaceous notosuchian crocodyliforms and other vertebrate taxa suggest the retention of episodic faunal links between Europe and Gondwana during most of the Cretaceous. Gondwana Research 28: 1197-1211.

Rio JP, Mannion PD, Tschopp E, Martin JE, Delfino M. 2020. Reappraisal of the morphology and phylogenetic relationships of the alligatoroid crocodylian Diplocynodon hantoniensis from the late Eocene of the United Kingdom. Zoological Journal of the Linnean Society 188: 579-629.

Ristevski J, Young MT, Andrade MB, Hastings AK. 2018. A new species of Anteophthalmosuchus (Crocodylomorpha, Goniopholididae) from the Lower Cretaceous of the Isle of Wight, United Kingdom, and a review of the genus. Cretaceous Research 84: 340-383.
Sachs S, Johnson M, Young M, Abel P. 2019a. The mystery of Mystriosaurus: redescribing the poorly known Early Jurassic teleosauroid thalattosuchians Mystriosaurus laurillardi and Steneosaurus brevior. Acta Palaeontologica Polonica 64: 565-579.

Sachs S, Young M, Abel P, Mallison H. 2019b. A new species of the metriorhynchid crocodylomorph Cricosaurus from the Upper Jurassic of southern Germany. Acta Palaeontologica Polonica 64: 343-356.

Salisbury SW, Naish D. 2011. Crocodilians. In: Batten DJ, ed. English Wealden fossils. London: Palaeontological Association, 305-369.

Sasso CD, Pasini G, Fleury G, Maganuco S. 2017. Razanandrongobe sakalavae, a gigantic mesoeucrocodylian from the Middle Jurassic of Madagascar, is the oldest known notosuchian. PeerJ 5: e3481.

Schwarz D, Salisbury SW. 2005. A new species of Theriosuchus (Atoposauridae, Crocodylomorpha) from the late Jurassic (Kimmeridgian) of Guimarota, Portugal. Geobios 38: 779-802.

Schwarz D, Fechner R. 2008. The first dentary of Lisboasaurus (Crocodylomorpha, ?Mesoeucrocodylia) from the Lower Cretaceous (Barremian) of Uña, Cuenca Province, Spain. Journal of Vertebrate Paleontology 28: 264-268.

Schwarz D, Raddatz M, Wings O. 2017. Knoetschkesuchus langenbergensis gen. nov. sp. nov., a new atoposaurid crocodyliform from the Upper Jurassic Langenberg Quarry (Lower Saxony, northwestern Germany), and its relationships to Theriosuchus. PLoS One 12: e0160617.

Sookias RB. 2020. Exploring the effects of character construction and choice, outgroups and analytical method on phylogenetic inference from discrete characters in extant crocodilians. Zoological Journal of the Linnean Society 189: 670-699.

Sweetman SC, Pedreira-Segade U, Vidovic SU. 2014. A new bernissartiid crocodyliform from the Lower Cretaceous Wessex Formation (Wealden Group, Barremian) of the Isle of Wight, southern England. Acta Palaeontologica Polonica 60: 257-269.

Tennant JP, Mannion PD. 2014. Revision of the Late Jurassic crocodyliform Alligatorellus, and evidence for allopatric speciation driving high diversity in western European atoposaurids. PeerJ 2: e599.

Tennant JP, Mannion PD, Upchurch P. 2016. Evolutionary relationships and systematics of Atoposauridae (Crocodylomorpha: Neosuchia): implications for the rise of Eusuchia. Zoological Journal of the Linnean Society 177: 854-936.

Venczel M, Codrea VA. 2019. A new Theriosuchus-like crocodyliform from the Maastrichtian of Romania. Cretaceous Research 100: 24-38.

Wilberg EW. 2015. What's in an Outgroup? The Impact of Outgroup Choice on the Phylogenetic Position of Thalattosuchia (Crocodylomorpha) and the Origin of Crocodyliformes. Systematic Biology 64: 621-637.

Wilberg EW. 2017. Investigating patterns of crocodyliform cranial disparity through the Mesozoic and Cenozoic. Zoological Journal of the Linnean Society 181: 189-208. 
Wilberg EW, Turner AH, Brochu CA. 2019. Evolutionary structure and timing of major habitat shifts in Crocodylomorpha. Scientific Reports 9: 514.

Yi H, Tennant JP, Young MT, Challands TJ, Foffa D, Hudson JD, Ross DA, Brusatte SL. 2017. An unusual small-bodied crocodyliform from the Middle Jurassic of Scotland, UK, and potential evidence for an early diversification of advanced neosuchians. Earth and Environmental Science Transactions of the Royal Society of Edinburgh 107: 1-12.

Young MT, Brusatte SL, Ruta M, Andrade MB. 2010. The evolution of Metriorhynchoidea (Mesoeucrocodylia, Thalattosuchia): An integrated approach using geometric morphometrics, analysis of disparity, and biomechanics. Zoological Journal of the Linnean Society 158: 801-859.

YoungMT,AndradeMB.2009. What is Geosaurus?Redescription of Geosaurus giganteus (Thalattosuchia: Metriorhynchidae) from the Upper Jurassic of Bayern, Germany. Zoological Journal of the Linnean Society 157: 551-585.
Young MT, Andrade MB, Etches S, Beatty BL. 2013. A new metriorhynchid crocodylomorph from the Lower Kimmeridge Clay Formation (Late Jurassic) of England, with implications for the evolution of dermatocranium ornamentation in Geosaurini. Zoological Journal of the Linnean Society 169: 820-848.

Young MT, Foffa D, Steel L, Etches S. 2020a. Macroevolutionary trends in the genus Torvoneustes (Crocodylomorpha: Metriorhynchidae) and discovery of a giant specimen from the Late Jurassic of Kimmeridge, UK. Zoological Journal of the Linnean Society 189: 483-493.

Young M, Sachs S, Pascal A, Foffa D, Herrera Y. 2020 b. Convergent evolution and possible constraint in the posterodorsal retraction of the external nares in pelagic crocodylomorphs. Zoological Journal of the Linnean Society 189: $494-520$.

Young MT, Tennant JP, Brusatte SL, et al. 2016. The first definitive Middle Jurassic atoposaurid (Crocodylomorpha, Neosuchia), and a discussion on the genus Theriosuchus. Zoological Journal of the Linnean Society 176: 443-462. 